\title{
Enhancing Early Spring Microclimate to Increase Carbon Resources and Productivity in June-bearing Strawberry
}

\author{
Lori J. Bushway and Marvin P. Pritts \\ Department of Horticulture, Cornell University, Ithaca, NY 14853
}

ADDITIONAL INDEX WORDS. carbon dioxide enrichment, Fragaria $\times$ ananassa, rowcovers, starch

\begin{abstract}
Aвstract. Effects of early spring cultural practices and microclimate manipulation on 'Jewel' strawberry (Fragaria ×ananassa Duch.) plant development, carbohydrate reserves, and productivity were measured in the field and under simulated early spring conditions in growth chambers. With traditional winter straw mulching practices of the northeastern and midwestern United States, starch content of overwintering leaves, crowns, and roots in the field declined by $51 \%, 78 \%$ and $69 \%$, respectively, during late winter and early spring. There was also a net loss in root biomass over winter and no new leaf growth before mid-April, suggesting that carbohydrate reserves could be limiting plant performance during the critical early growth and flowering phase in spring. In growth chambers, exposure to $\mathrm{CO}_{2}$ levels between 700 to $1000 \mathrm{~mL} \cdot \mathrm{L}^{-1}$ significantly increased photosynthetic rates of overwintering and spring leaves compared to ambient $\mathrm{CO}_{2}$ levels. Elevated $\mathrm{CO}_{2}$ in growth chambers also accelerated flower development, reduced depletion of starch reserves in roots, and increased starch accumulation in crowns. In the field, early removal of straw and application of spunbonded rowcover accelerated plant development, increased starch accumulation in the leaves, and increased photosynthetic rates of overwintering and spring leaves. Elevating the $\mathrm{CO}_{2}$ levels under rowcover further increased photosynthetic rates and advanced plant development and starch accumulation, but not significantly above rowcover alone. Carbohydrate losses later in the season during flower development were reduced when rowcover was applied in early spring. Total fruit yield was as much as $\mathbf{4 8 \%}$ higher for plants under rowcover in early spring than those that had no cover and an additional $9 \%$ higher when $\mathrm{CO}_{2}$ was elevated. Yield improvements were attributed mostly to an increase in the number of marketable secondary and tertiary fruit than to an increase in mean fruit size. The economics of rowcover use is favorable if the material is reused. The added expense of $\mathrm{CO}_{2}$ gas and the resulting marginal gains would not make field $\mathrm{CO}_{2}$ enrichment an economically viable practice for strawberry growers using the method herein.
\end{abstract}

In cool growing areas, strawberry plants (Fragaria xananassa) grow most rapidly in spring, at the same time as they flower and fruit (May et al., 1994). Early spring is also the time when carbohydrate reserves are low. Strong competition among fruit and vegetative sinks for limited carbon resources could be a major factor limiting fruit production in strawberry plants.

Specific cultural practices may influence plant carbohydrate resources in early spring. In the northeastern and midwestern United States, straw mulch is applied traditionally in late fall over June-bearing strawberry plants and left in place until new leaf growth has started in April (Shoemaker, 1975). The benefits of this practice include decreasing winter injury and, as a result, increasing yield over plots with no winter straw mulch (Boyce and Reed, 1983; Collins, 1966). However, when straw mulch is in place, light availability and plant carbon production are limited. Plants under mulch must, therefore, rely on stored carbohydrate reserves in early spring to support metabolism and new vegetative growth. Carbohydrate reserves in early spring may be insufficient for optimum vegetative growth and subsequent fruiting.

Synthetic rowcovers have been used as an alternative to straw mulch in early spring to enhance plant microclimate (light and temperature) while maintaining plant protection from seasonally low temperatures. Spunbonded rowcovers allow $>80 \%$ of the available photosynthetically active radiation $(P A R)$ to reach a crop and increase air, plant and soil temperatures, especially in the daytime (Hamamoto, 1996; Loy and Wells, 1982). Spring appli-

Received for publication 4 Mar 2001. Accepted for publication 6 Feb. 2002. The authors wish to thank Todd Dawson, Tim Setter, and Chris Watkins for use of their labs, Jeff Melkonian and Mary Jo Kelly for technical assistance, and Lailiang Cheng and Ian Merwin for reviewing a draft manuscript. cation of spunbonded rowcover in strawberry plots has accelerated leaf growth, flowering, fruiting, and increased productivity (Gast and Pollard, 1989; Gent, 1990; Pollard and Cundari, 1988; Pritts et al., 1989). However, the physiological bases for these responses have not been determined.

When temperature and light availability are increased under rowcovers, $\mathrm{CO}_{2}$ may become the next essential factor limiting photosynthetic rates and plant productivity. Addition of $\mathrm{CO}_{2}$ may improve assimilation rates, which could further accelerate new leaf development and reduce competition among reproductive sinks. Strawberry plants increase growth and productivity in response to elevated $\mathrm{CO}_{2}$ during long-term exposure in greenhouse environments (Chen et al., 1997a-e; Deng and Woodward, 1998; Keutgen et al., 1997; Sung and Chen, 1991). However, it is not clear if short-term exposure to $\mathrm{CO}_{2}$ enrichment before bloom can enhance plant carbon resources, promote plant development, or improve yields, particularly when temperatures are cool.

In this study, the influence of spring cultural practices on carbohydrate reserves and yield was investigated. The objectives were to 1) quantify changes in carbohydrate reserves during late winter and spring in a conventionally treated matted row strawberry planting, 2) determine if strawberry plants are responsive to short-term $\mathrm{CO}_{2}$ enrichment before bloom, and 3) determine if certain cultural practices, including $\mathrm{CO}_{2}$ enrichment, can improve carbohydrate reserves, photosynthetic rates, growth, and strawberry yield in the field.

\section{Materials and Methods}

CARBOHYDRATE LEVELS DURING WINTER AND SPRING (EXPT. 1). In May 1997, more than 50 dormant crowns of 'Jewel' Junebearing strawberry plants were planted individually into $1.5-\mathrm{L}$ 
plastic pots containing 1 peat : 1 perlite : 1 vermiculite (by volume). The plants were grown outdoors at Cornell Orchards, Ithaca, N.Y., at a pot-to-pot spacing of $20 \mathrm{~cm}$ and received standard care (Pritts and Handley, 1998). Flowers and runners were removed throughout the summer. In late November, three trenches, $\approx 15 \mathrm{~cm}$ deep, were dug and the plants were placed pot to pot in the ground. The plants were covered with straw mulch until mid-April for winter protection.

Starting on 20 Feb. 1997 and continuing at 2-week intervals until $17 \mathrm{Apr}$., three potted plants were harvested at random from the straw mulch-covered field planting. The soil was washed off each plant and the plant was divided into roots, crowns, and leaves. Immediately after washing, each of these plant organs was frozen in liquid $\mathrm{N}$ and stored at $-15^{\circ} \mathrm{C}$ until lyophilized. Dried tissue was weighed to obtain total biomass of leaves, crowns, and roots of each plant. The tissue was then ground with an Intermediate Wiley Mill (Thomas Scientific Co., Philadelphia, Penn.) to pass a 20-mesh (1.27-mm) screen. A 50-mg subsample of leaves, crowns, and roots from each plant at each harvest was stored in a freezer at $-15^{\circ} \mathrm{C}$ until used for carbohydrate analysis.

Soluble sugars (glucose, fructose, and sucrose) and starch in leaves, crowns, and roots were determined using an enzymatic microanalytical method in enzyme-linked immunosorbent assay (ELISA) plates as described by Cairns (1987) with the modifications of Setter (1996). Soluble sugars in tissue samples were extracted with ethanol, and glucose, fructose, and sucrose levels were measured in an aliquot of the ethanol extraction while starch was determined in the insoluble residue. All soluble sugar and starch assays were done in duplicate and the measurements compared against glucose standards. Glucose, fructose, and sucrose concentrations followed the same trend in each plant tissue so their values were added to obtain a single total soluble sugar concentration. Soluble sugar and starch concentrations in each type of tissue was multiplied by the biomass of the respective organ to obtain total soluble sugar and starch content of that organ. The effect of harvest date on carbohydrates and biomass was analyzed by analysis of variance (ANOVA), following GLM procedures in SPSS (SPSS, Inc., Chicago, Ill.).

STRAWBERry Plant RESPONSE TO ELEVATED CO 2 (EXPT. 2). In Apr. 1998, 20 potted plants were selected randomly from the same straw mulch-covered plots described above. These dormant strawberry plants were transplanted to 2 -L plastic pots using the medium described earlier, decaying leaves were removed, and soil was rinsed off the remaining leaves. At random, 10 of the plants were assigned to a growth chamber where $\mathrm{CO}_{2}$ was maintained at 700 to $1000 \mathrm{~mL} \cdot \mathrm{L}^{-1}$ during a 14-h day. A computer control system (Enviromac; Remote measuring Systems, Inc. Seattle, Wash.) connected to an infrared gas analyzer (421P; Nova Analytical Systems, Inc., Niagara Falls, N.Y.) and a compressed gas source were used to monitor and maintain $\mathrm{CO}_{2}$ concentration. The other 10 plants were assigned to a chamber with ambient $\mathrm{CO}_{2}$ levels of $\approx 360$ to $390 \mathrm{~mL} \cdot \mathrm{L}^{-1}$. The day length $(14 \mathrm{~h})$ and day temperature $\left(15^{\circ} \mathrm{C}\right.$ day $)$ of both chambers were set to the midspring average (late April to early May) for Ithaca, N.Y., whereas the night temperature $\left(10{ }^{\circ} \mathrm{C}\right)$ was $4{ }^{\circ} \mathrm{C}$ above average because of growth chamber limitations. The photosynthetic photon flux $(P P F)$ was $\approx 450$ to $500 \mathrm{mmol} \cdot \mathrm{m}^{-2} \cdot \mathrm{s}^{-1}$. Treatments continued until plants began to bloom, $\approx 6$ weeks after forcing, then all plants were moved to a common greenhouse environment where ambient $\mathrm{CO}_{2}$ levels were 360 to $390 \mathrm{~mL} \cdot \mathrm{L}^{-1}$.

Photosynthetic rates $\left(\mathrm{mmol} \cdot \mathrm{m}^{-2} \cdot \mathrm{s}^{-1}\right)$ were measured with a portable photosynthesis system (LI-6200; LI-COR, Lincoln,
Nebr.) 12, 25, and $49 \mathrm{~d}$ after the start of treatments. Photosynthetic rates were determined for one representative leaf on each plant in the two treatments. On the first measurement day, no spring leaves had reached full expansion, so the greenest, healthiest overwintering leaf on each plant was chosen for measurement. On all other measurement days, the youngest fully expanded spring leaf on each plant was chosen for measurement. Leaves were measured under treatment $\mathrm{CO}_{2}$ conditions on the second measurement day and ambient $\mathrm{CO}_{2}$ on the final measurement day after treatments ended. The effect of prebloom $\mathrm{CO}_{2}$ levels on mean photosynthetic rates of leaves on each day was analyzed separately by ANOVA following GLM procedures in SPSS.

In early spring at the start of the treatment period, five additional dormant strawberry plants were randomly selected from the same plot as the plants in the experiment. These plants were harvested to obtain biomass and carbohydrate content of overwintering leaves, crowns, and roots of dormant plants before prebloom treatments began. Six weeks later, five plants from each prebloom $\mathrm{CO}_{2}$ treatment were harvested to examine the same plant characteristics. The harvests, tissue measurements, tissue assays, and data analysis were conducted as described in the preceding experiment.

A second growth chamber experiment (Expt. 3) was initiated in 1999 following similar procedures, but with a few modifications. In this experiment, eight plants were included in each treatment. Photosynthetic rates were measured 23 and $29 \mathrm{~d}$ after the start of the treatments using the greenest, healthiest overwintering leaf and youngest fully expanded spring leaf on each plant in each treatment on each day. Further, unlike the first growth chamber experiment in which a group of plants from each treatment was harvested on a single calendar date, three plants from each treatment were harvested on the first day that bloom appeared on each plant. Evidence from the first experiment indicated that treatments might influence rate of development, so we attempted to eliminate the possibility that observed differences were influenced by phenological stage. A good estimate of yield was not obtained in either growth chamber experiment because the chamber environment was not conducive to adequate pollination of flowers or fruit set.

EFFECTS OF CUltural PRACTICES (ExPT. 4). In May 1997, 300 dormant 'Jewel' strawberry plants were planted in a matted row system ( $1.2 \mathrm{~m}$ between rows and $0.5 \mathrm{~m}$ between plants in rows) at Cornell Orchards. The plants received standard care (Pritts and Handley, 1998); flowers were removed during the first growing season and runners filled in the rows. In late Nov. 1997, a covering of $15 \mathrm{~cm}$ of rye (Secale cereale L.) straw mulch was applied for winter protection. Late in Mar. 1998, after the last snow melted, each of the six rows was divided into four $6 \mathrm{~m}$ sections. In each of the 24 sections, a plant was randomly selected and tagged for later gas exchange measurements and plant harvest. Overwintering leaves that expanded the previous fall and survived the winter were counted and marked. In a randomized block design, one of four cultural practices was assigned to each 6-m section in each of the six rows: 1) standard treatment; winter straw mulch left in place until mid to late April; 2) early mulch removal (no cover) treatment; winter straw mulch removed in March and plants left uncovered for the remainder of the growing season; 3) rowcover treatment; straw mulch removed in March and plants covered immediately with spunbonded polypropylene rowcover (Typar T-518; Reemay, Inc., Old Hickory, Tenn.); and 4) elevated $\mathrm{CO}_{2}$ treatment; straw mulch was removed in March, drip irrigation lines $\left(1.17 \mathrm{~mL} \cdot \mathrm{m}^{-1} \cdot \mathrm{s}^{-1}, 30-\mathrm{cm}\right.$ emitter spacing; 
Chapin Watermatics Inc., Watertown, N.Y.) were positioned on the soil surface in a loop around plants in each replicate, plants were covered with spunbonded polypropylene rowcover, and supplemental $\mathrm{CO}_{2}$ was supplied through drip tape irrigation lines. This latter treatment was based on a similar $\mathrm{CO}_{2}$ delivery system used under polyethylene tunnels (Hartz et al., 1991). Pure $\mathrm{CO}_{2}$ was delivered from tanks of compressed gas through plastic tubing to the drip tape. It was then released through the emitters and mixed readily with the air under the rowcover. Using instantaneous gas measurements from a portable gas analyzer (LI6200 ), the tank pressure was set to maintain $\mathrm{CO}_{2}$ levels between 600 and $1000 \mathrm{~mL} \cdot \mathrm{L}^{-1}$ under the rowcover. Monitoring was done periodically throughout the treatment period and any needed adjustments in flow rates were made. The $\mathrm{CO}_{2}$ level under the rowcover was highly dependent on current wind conditions as no automated regulator was used to adjust flow rates. The $\mathrm{CO}_{2}$ was supplemented only between 0800 and $1700 \mathrm{HR}$ on days without rain. Day temperatures under rowcover were as much as $4{ }^{\circ} \mathrm{C}$ higher than ambient on sunny days, but near ambient on cloudy days and at night. Soil temperature was as much as $2{ }^{\circ} \mathrm{C}$ higher under rowcover treatments. Carbon dioxide levels under treatment 3 (rowcover without supplementation) were near ambient. Treatments stopped and rowcovers were removed when the first flowers appeared in each treatment so pollinators could access flowers.

Photosynthetic rates were measured and analyzed as described above. Measurements were completed 23 and $26 \mathrm{~d}$ after treatments began at midday, in full sun, under treatment conditions for one overwintering leaf and one spring leaf in each of the six replicates of the four treatments. The elevated $\mathrm{CO}_{2}$ treatment was measured at $\approx 600 \mathrm{~mL} \cdot \mathrm{L}^{-1}$ and all other treatments at ambient $\mathrm{CO}_{2}$ $\left(\approx 360 \mathrm{~mL} \cdot \mathrm{L}^{-1}\right)$. The straw was replaced over the measurement device when rates were determined for plants in the late straw removal treatment. The rowcover also was replaced when rates were determined for plants in the elevated $\mathrm{CO}_{2}$ and rowcover treatments. Although rowcover reduced light levels by $\approx 18 \%$, plants were still exposed to light levels significantly above saturation (Ferree and Stang, 1988; Kerkhoff et al., 1988).

A whole plant harvest of six plants selected previously from each treatment was conducted 4 weeks after the treatments began to determine biomass and starch content of overwintering leaves, crowns, and roots before flowering. This harvest occurred $5 \mathrm{~d}$ before the first flowers were observed on plants under rowcover. The harvests, tissue measurements, tissue assays, and data analyses were conducted as described above.

Yields were determined for each treatment by harvesting ripe fruit from a subsample of plants in each of the six replicates of the four treatments. Two representative $1 \mathrm{~m}$ sections of each replicate were harvested. Ripe fruit were sorted, counted, and weighed by position on the inflorescence: primary, secondary, or tertiary. Fruit harvest continued every 2 to $4 \mathrm{~d}$ in each section until average fruit weight fell below $5 \mathrm{~g}$. All harvested fruit were used in determining yields. Treatment effects on carbohydrate content, total yield, yield from each fruit position, number of fruit at each fruit position, and average fruit size were analyzed by ANOVA following GLM procedures in SPSS.

In May 1998, a similar field experiment was conducted (Expt. $5)$, except that strawberry plants were first planted into pots to improve uniformity over matted rows. Dormant crowns (selected for uniformity in size) of 'Jewel' strawberry were planted in 2-L plastic pots containing a medium of 1 peat : 1 perlite : 1 vermiculite (by volume). The pots containing plants were set into the ground, all runners were removed during the growing season, and plants were mulched for winter in late November. In late March, plants were uncovered, removed from pots, and transplanted into rows in the field. Spacing was $1.2 \mathrm{~m}$ between rows and 27 random strawberry plants were planted in each of six rows at a $0.5-\mathrm{m}$ spacing. Each row was divided into three sections of nine plants each. Four plants in each section were randomly selected and flagged for later whole plant harvests. Three treatments were randomly assigned to the three plots in each of the six rows. Unlike the previous year, the standard straw-mulch treatment was excluded because the first field experiment revealed its obvious negative impact on plant yield. To reduce the rate of dissipation of the $\mathrm{CO}_{2}$ through the rowcover, two layers of cover were used. On the windiest days, $\mathrm{CO}_{2}$ enrichment ranged between 425 and $775 \mathrm{~mL} \cdot \mathrm{L}^{-1}$ and on calmest days ranged between 500 and 1600 $\mathrm{mL} \cdot \mathrm{L}^{-1}$. Levels of $\mathrm{CO}_{2}$ under rowcover without supplementation were near ambient. However, PPF was reduced by $\approx 30 \%$ and temperatures were elevated as much as $3{ }^{\circ} \mathrm{C}$ on sunny days under two layers of rowcover.

Leaf photosynthetic rates were measured 12,37 , and $47 \mathrm{~d}$ after treatments began and analyzed as described above. On the first measurement day, no spring leaves had reached full expansion so only the healthiest overwintering leaf on each plant was chosen. On the second measurement day, only the youngest fully expanded spring leaf on one plant in each treatment replicate was chosen. The final measurement day was $4 \mathrm{~d}$ after first flowers appeared in the elevated $\mathrm{CO}_{2}$ treatment and $1 \mathrm{~d}$ after first flower in the rowcover treatment. The youngest fully expanded spring leaf on one plant in each treatment replicate was measured under ambient $\mathrm{CO}_{2}$ and full sun.

As in the first field experiment, six dormant strawberry plants were randomly selected from the experiment field at the start of the treatment period and harvested to obtain biomass and starch content of overwintering leaves, crowns, and roots. Three additional whole plant harvests were performed throughout the spring to determine season-long effects of the prebloom treatments. Evidence from the previous year indicated that treatments might influence rate of development, so unlike the first field experiment, these harvests were executed at the same phenological stage for each treatment, rather than calendar date.

\section{Results}

Carbohydrate levels during Winter and SPRING. With standard mulching (Expt. 1), no visible signs of new leaf growth occurred before 17 Apr. 1998. Biomass and starch content of overwintering leaves tended to decline through early spring (Table 1), as much as $45 \%$ by mid-March compared to midwinter levels. Crown biomass and starch content followed a similar declining trend, except that the change was minimal up to $20 \mathrm{Mar}$. and then declined sharply (Table 1). Root biomass decreased by $>40 \%$ between 20 Feb. and 20 Mar., while root starch content decreased steadily throughout late winter and early spring (Table 1). On 17 Apr., starch content of roots was less than one third of what it was at the first harvest in February. Patterns in soluble sugar content were similar to those for starch content (data not presented; Bushway, 2000).

StraWberry Plant Response To Elevated $\mathrm{CO}_{2}$. In growth chambers (Expts. 2 and 3), overwintering leaves exposed to elevated $\mathrm{CO}_{2}$ had significantly higher mean photosynthetic rates than overwintering leaves exposed to ambient $\mathrm{CO}_{2}(P<0.005$, Fig. 1). A similar trend was observed in spring leaves when they 
Table 1. Patterns of total biomass and starch content of overwintering leaves, crowns and roots of 'Jewel' strawberry plants under winter mulch protection in early Spring 1998 (Expt. 1) $(\mathrm{n}=3)$.

\begin{tabular}{|c|c|c|c|c|c|c|}
\hline \multirow[b]{3}{*}{ Date } & \multicolumn{3}{|c|}{ Biomass (g) } & \multicolumn{3}{|c|}{ Starch (mg) } \\
\hline & Overwintering & & & Overwintering & & \\
\hline & leaves & Crowns & Roots & leaves & Crowns & Roots \\
\hline 20 Feb. & 6.3 & 4.6 & 15.0 & 37.0 & 175.2 & 1085.8 \\
\hline 6 Mar. & 6.6 & 5.5 & 12.8 & 40.6 & 194.6 & 726.5 \\
\hline 20 Mar. & 5.3 & 5.1 & 8.6 & 22.7 & 182.3 & 685.1 \\
\hline 3 Apr. & 5.2 & 3.8 & 8.5 & 23.6 & 61.2 & 513.7 \\
\hline 17 Apr. & 4.7 & 3.8 & 7.3 & 18.0 & 38.8 & 334.7 \\
\hline SE & 0.7 & 0.6 & 1.6 & 3.5 & 31.8 & 102.5 \\
\hline$P^{\mathrm{z}}$ & NS & NS & 0.005 & 0.004 & 0.01 & 0.005 \\
\hline
\end{tabular}

${ }^{\mathrm{z}}$ Significance level for the linear response of the measured variable over time (days after 20 Feb. 1998). ${ }^{\text {NSNonsignificant. }}$

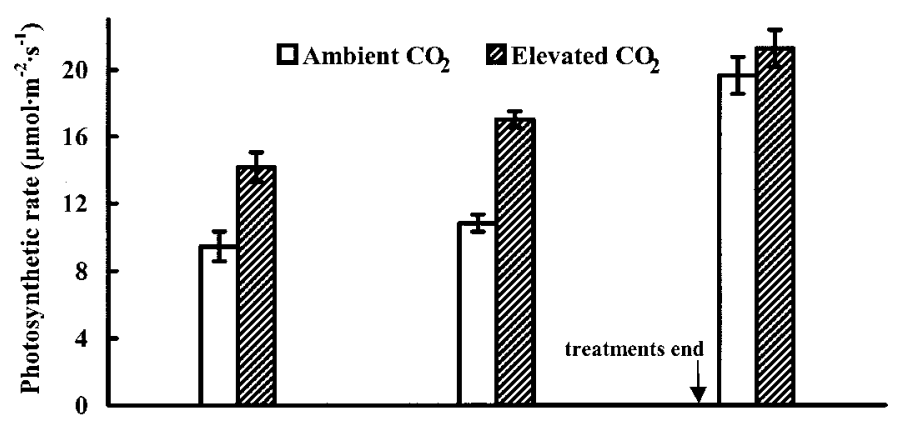

$12 \quad 25$

Days after treatments began

Fig. 1. Mean photosynthetic rates of leaves of 'Jewel' strawberry plants growing in ambient and elevated $\mathrm{CO}_{2}$ growth chamber environments at three dates after treatments began (Expt. 2). Overwintering leaves were measured at day 12 and new spring leaves were measured thereafter. Day 49 was after treatments were discontinued, so plants were measured at ambient $\mathrm{CO}_{2}$ levels. Vertical lines $=\mathrm{SE}$ $(\mathrm{n}=10)$.

were measured under the same conditions $(P<0.001)$. Moreover, photosynthetic rates of overwintering leaves were nearly equal to that of new spring leaves in their respective treatments. When spring leaves in both treatments were measured again at ambient $\mathrm{CO}_{2}$ levels after plants were moved to a common environment, the 6 weeks of exposure to elevated $\mathrm{CO}_{2}$ had no significant effect on photosynthesis rate. The same trends in rates were observed in the second growth chamber experiment the following year (data not presented; Bushway, 2000).

In Expt. 2, biomass of overwintering leaves declined significantly between the dormant and bloom harvest in the ambient $\mathrm{CO}_{2}$ treatment $(5.9 \mathrm{~g}$ to $2.9 \mathrm{~g}, P<0.01)$ but not in the elevated $\mathrm{CO}_{2}$ treatment ( $5.9 \mathrm{~g}$ to $4.5 \mathrm{~g}$ ). Crown and root biomass increased significantly during this treatment period in the elevated $\mathrm{CO}_{2}$ treatment ( $7.3 \mathrm{~g}$ to $11.4 \mathrm{~g}, P<0.01$ and $14.7 \mathrm{~g}$ to $22.6 \mathrm{~g}, P<0.01$ ) but not in the ambient $\mathrm{CO}_{2}$ treatment. At the bloom harvest, the only significant biomass difference between treatments was in floral parts; biomass was greater under elevated $\mathrm{CO}_{2}(1.8 \mathrm{~g}$ vs. 1 $\mathrm{g}, P<0.02)$. Patterns were similar in Expt. 3, except there was no significant difference in the biomass of floral parts (data not presented: Bushway, 2000). However, strawberry plants in the elevated $\mathrm{CO}_{2}$ treatment flowered an average of $4 \mathrm{~d}$ ahead of plants in the ambient $\mathrm{CO}_{2}$ treatment in both years.

During the treatment period in 1998 (Expt. 2), the starch content of overwintering leaves increased significantly in plants growing in a $\mathrm{CO}_{2}$ enriched environment and decreased in plants growing in an ambient $\mathrm{CO}_{2}$ environment compared to dormant values, while starch content in roots declined in both treatments (Table 2). Starch in crowns declined significantly in the ambient $\mathrm{CO}_{2}$ treatment, but not in the elevated $\mathrm{CO}_{2}$ treatment. At the bloom harvest, plants in the elevated $\mathrm{CO}_{2}$ treatment had nearly five times the starch content in overwintering leaves as those in the ambient $\mathrm{CO}_{2}$ treatment (Table 2). Spring leaves, crowns, and roots of plants exposed to elevated $\mathrm{CO}_{2}$ before bloom also had a significantly higher total starch content than the same organs of plants growing in ambient $\mathrm{CO}_{2}$ conditions. Plants in the elevated $\mathrm{CO}_{2}$ treatment had three times the amount of spring leaf starch, two times the amount of crown starch, and four times the amount of root starch as those in the ambient $\mathrm{CO}_{2}$ treatment. Overall, total mean plant starch content decreased by $300 \mathrm{mg}$ under ambient $\mathrm{CO}_{2}$ between the dormant and bloom harvest, while it increased by nearly $700 \mathrm{mg}$ under elevated $\mathrm{CO}_{2}$. Similarly, in 1999 (Expt. 3 ), plants exposed to elevated $\mathrm{CO}_{2}$ before bloom had significantly higher total starch content in crowns $(68 \%, P<0.01)$ and roots

Table 2. Effect of prebloom $\mathrm{CO}_{2}$ enrichment in the growth chamber on starch content of plant parts of 'Jewel' strawberry at first flower in 1998 (Expt. 2) $(n=5)$.

\begin{tabular}{lcrrr}
\hline \hline & \multicolumn{2}{c}{ Starch $(\mathrm{mg})$} & & \\
\cline { 2 - 5 } Treatment & Overwintering leaves & Spring leaves & Crown & \\
\hline Dormant harvest & 40.8 & & 158.5 \\
Bloom harvest & & & \\
$\quad$ Ambient $\mathrm{CO}_{2}$ & $17.1^{\mathrm{z}}$ & 352.1 & $101.6^{\mathrm{z}}$ & 230.3 \\
Elevated $\mathrm{CO}_{2}$ & $94.2^{\mathrm{y}}$ & 1056.0 & $26.9^{\mathrm{z}}$ \\
SE & 13.5 & 96.7 & $112.9^{\mathrm{x}}$ \\
$P^{\mathrm{z}}$ & 0.01 & 0.001 & 0.007 & 0.02 \\
\hline
\end{tabular}

${ }^{\mathrm{z}}$ Significance level using an unpaired $t$ test for the difference between $\mathrm{CO}_{2}$ treatments.

y Represents an increase $(P<0.05)$ from the dormant value of the corresponding plant organ.

${ }^{x}$ Represents a decline $(P<0.05)$ from the dormant value of the corresponding plant organ. 


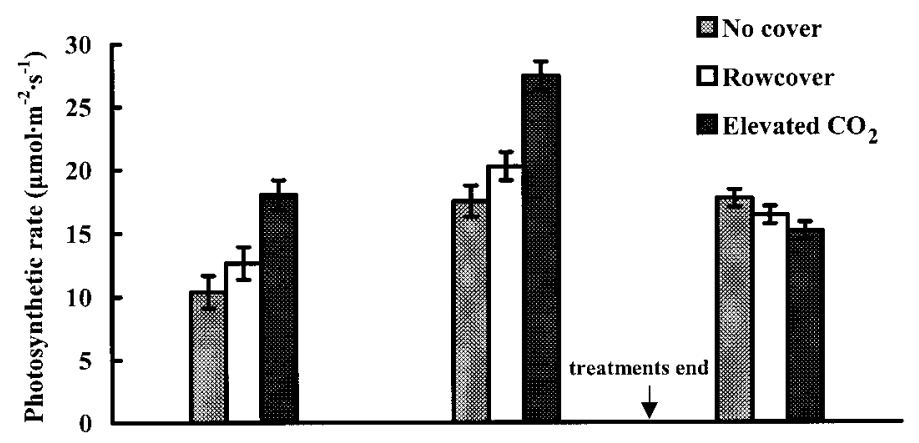

12

37

Days after treatments began

$(83 \%, P<0.08)$ than plants growing under ambient $\mathrm{CO}_{2}$ conditions. There were no significant differences between treatments in total soluble sugar content of overwintering leaves, crowns, and roots in either year (data not presented; Bushway, 2000).

EFFects of CUltural PRACTICES. Trends in leaf photosynthesis rates in the field (Expts. 4 and 5) were similar to those observed in the growth chambers (Expts. 2 and 3). Overwintering leaves
Fig. 2. Mean photosynthetic rates of leaves of 'Jewel' strawberry plants in no cover, rowcover, and elevated $\mathrm{CO}_{2}$ treatments in the field at three dates after treatments began in 1999 (Expt. 4). Overwintering leaves were measured at treatment $\mathrm{CO}_{2}$ levels at day 12 and new spring leaves were measured thereafter. Day 47 was after treatments were discontinued, so plants were measured at ambient $\mathrm{CO}_{2}$ levels. Vertical lines $=\mathrm{SE}(\mathrm{n}=6)$.

and spring leaves exposed to elevated $\mathrm{CO}_{2}$ had significantly higher mean photosynthetic rates during the treatment period than overwintering leaves at ambient $\mathrm{CO}_{2}$ under rowcover and no cover $(P<0.003, P<0.001$, Fig. 2$)$. Exposure to elevated $\mathrm{CO}_{2}$ before bloom only marginally lowered leaf photosynthesis rates after enrichment ended $(P<0.06)$. Additionally, mean photosynthetic rates of overwintering and spring leaves in the rowcover and no cover treatments were not significantly different, even though the light levels were reduced under the covers.

Flowers first appeared $\approx 5$ weeks after the treatments were initiated in 1998 and 6 weeks after the treatments were initiated in 1999. In both years, plants in elevated $\mathrm{CO}_{2}$ were the first to flower. Plants in the rowcover-only treatment flowered 2 to $3 \mathrm{~d}$ later, plants in the no cover treatment bloomed 7 to $10 \mathrm{~d}$ later, and plants in the straw treatment flowered $12 \mathrm{~d}$ later. In 1998, there were significant differences among treatments in spring leaf biomass and starch content in all measured plant organs (Table 3),

Table 3. The effect of prebloom treatments in the field on total biomass and starch content of 'Jewel' strawberry plant organs 4 weeks after treatments began in 1998 (Expt. 4) $(\mathrm{n}=6)$.

\begin{tabular}{|c|c|c|c|c|c|c|c|c|}
\hline \multirow[b]{2}{*}{ Treatment } & \multicolumn{4}{|c|}{ Biomass (g) } & \multicolumn{4}{|c|}{ Starch (mg) } \\
\hline & $\begin{array}{c}\text { Old } \\
\text { leaves }\end{array}$ & $\begin{array}{l}\text { New } \\
\text { leaves }\end{array}$ & Crown & Root & $\begin{array}{c}\text { Old } \\
\text { leaves }\end{array}$ & $\begin{array}{c}\text { New } \\
\text { leaves }\end{array}$ & Crown & Root \\
\hline Straw & 4.0 & 0.9 & 4.1 & 4.2 & 13.2 & 15.0 & 16.9 & 34.4 \\
\hline No cover & 5.2 & 2.1 & 5.5 & 4.6 & 27.0 & 19.3 & 40.2 & 53.1 \\
\hline Rowcover & 7.3 & 4.3 & 8.0 & 7.9 & 30.5 & 23.0 & 44.1 & 66.3 \\
\hline Elevated $\mathrm{CO}_{2}$ & 6.8 & 3.1 & 6.6 & 3.5 & 40.4 & 29.1 & 49.7 & 70.2 \\
\hline SE & 1.0 & 0.5 & 1.2 & 1.5 & 2.6 & 1.7 & 3.2 & 5.2 \\
\hline$P^{\mathrm{z}}$ & NS & 0.001 & NS & NS & 0.001 & 0.001 & 0.001 & 0.001 \\
\hline
\end{tabular}

${ }^{\mathrm{Z}}$ Overall treatment effect. To separate means with an $\mathrm{LSD}_{0.05}$, multiply the SE by 2.16 . ${ }^{\mathrm{NS}}$ Nonsignificant.

Table 4. Total biomass and starch content of 'Jewel' strawberry plant organs over time in response to prebloom treatments in the field in 1999 (Expt. 5) $(\mathrm{n}=6)$.

\begin{tabular}{|c|c|c|c|c|c|c|c|c|c|c|}
\hline \multirow[b]{2}{*}{ Time } & \multirow[b]{2}{*}{ Treatment } & \multicolumn{5}{|c|}{ Biomass (g) } & \multicolumn{4}{|c|}{ Starch (mg) } \\
\hline & & $\begin{array}{c}\text { Old } \\
\text { leaves }\end{array}$ & $\begin{array}{l}\text { New } \\
\text { leaves }\end{array}$ & Crown & Root & $\begin{array}{c}\text { Reproductive } \\
\text { organs }\end{array}$ & $\begin{array}{c}\text { Old } \\
\text { leaves }\end{array}$ & $\begin{array}{l}\text { New } \\
\text { leaves }\end{array}$ & Crown & Root \\
\hline Dormant & & 10.0 & & 13.3 & 25.1 & & 95.7 & & 281.9 & 892.1 \\
\hline \multirow[t]{5}{*}{ First flower } & No cover & $3.7^{*}$ & 18.4 & 13.3 & $18.7^{*}$ & 2.6 & 76.5 & 573.5 & 315.9 & $362.0^{*}$ \\
\hline & Rowcover & $4.3^{*}$ & 18.9 & 11.6 & $20.3^{*}$ & 1.5 & 97.7 & 750.0 & 253.6 & $501.3^{*}$ \\
\hline & Elevated $\mathrm{CO}_{2}$ & $5.2^{*}$ & 20.1 & 12.6 & $18.4^{*}$ & 1.5 & 138.0 & 852.5 & 243.0 & $443.9^{*}$ \\
\hline & SE & 0.9 & 1.5 & 0.9 & 1.2 & 0.2 & 28.1 & 60.2 & 40.9 & 96.2 \\
\hline & $P^{\mathrm{z}}$ & NS & NS & NS & NS & NS & 0.05 & 0.02 & NS & NS \\
\hline \multirow[t]{5}{*}{ Green fruit } & No cover & & 25.0 & 12.5 & $20.7^{*}$ & 6.6 & & 499.6 & 261.5 & $249.0^{*}$ \\
\hline & Rowcover & & 29.5 & 12.5 & $20.5^{*}$ & 6.0 & & 1268.3 & 264.0 & $326.9^{*}$ \\
\hline & Elevated $\mathrm{CO}_{2}$ & & 32.1 & 13.6 & $16.8^{*}$ & 7.3 & & 1129.5 & 244.7 & $227.8^{*}$ \\
\hline & SE & & 1.8 & 0.5 & 1.5 & 0.7 & & 70.0 & 31.0 & 47.3 \\
\hline & $P^{\mathrm{z}}$ & & 0.03 & NS & NS & NS & & 0.001 & NS & NS \\
\hline \multirow[t]{5}{*}{ Ripe fruit } & No cover & & 33.1 & 11.5 & $17.8^{*}$ & 23.0 & & 813.9 & $157.6^{*}$ & $130.6^{*}$ \\
\hline & Rowcover & & 46.6 & 15.1 & 24.6 & 24.8 & & 1493.8 & 271.4 & $242.7^{*}$ \\
\hline & Elevated $\mathrm{CO}_{2}$ & & 31.6 & 13.5 & 25.6 & 18.5 & & 650.3 & 244.7 & $295.6^{*}$ \\
\hline & SE & & 3.2 & 0.9 & 1.5 & 2.4 & & 126.5 & 34.0 & 37.0 \\
\hline & $P^{\mathrm{z}}$ & & 0.01 & 0.04 & 0.005 & NS & & 0.002 & NS & 0.02 \\
\hline
\end{tabular}

${ }^{\mathrm{z}}$ Overall treatment effect. To separate means with a $\mathrm{LSD}_{0.05}$, multiply the sE by $2.3 .{ }^{\mathrm{NS},}{ }^{*}$ Nonsignificant or significant decline $(P<0.05)$ from the dormant value of the corresponding plant organ. 

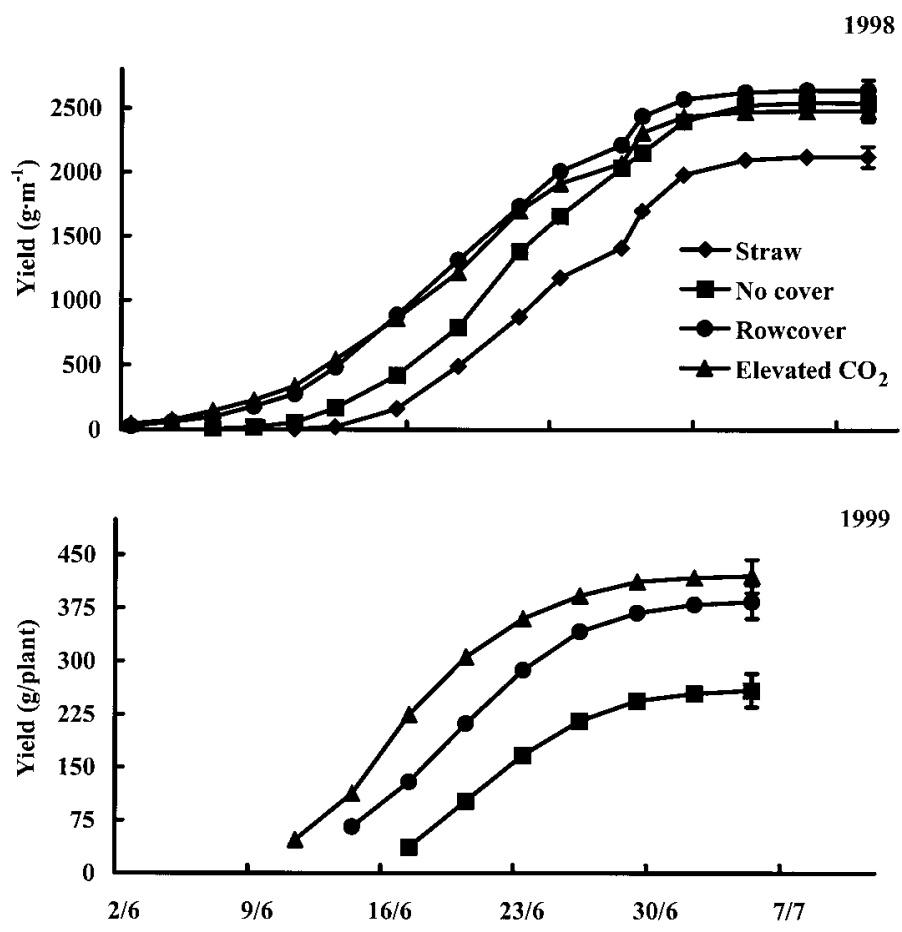

Date (day/month)

Fig. 3. Effect of prebloom treatments on field yield of 'Jewel' strawberry plants. Vertical lines $=\operatorname{SE}(n=6)$.

but in 1999 only the starch content of overwintering and spring leaves was significantly higher in plants exposed to elevated $\mathrm{CO}_{2}$ (Table 4).

Biomass of overwintering leaves, roots, and starch content of roots declined significantly $(P<0.05)$ between the dormant and bloom harvests in 1999 for all treatments (Table 4). Overall, total mean plant starch content increased in all treatments from the start of treatment to first bloom, an average of $400 \mathrm{mg}$ in the elevated $\mathrm{CO}_{2}$ treatment and $300 \mathrm{mg}$ in the rowcover treatment, but $<60 \mathrm{mg}$ in the no cover treatment.

Two weeks after the bloom harvest in each treatment, at the start of rapid fruit expansion, mean starch content of spring leaves was still significantly different among treatments (Table 4), but not the starch content or biomass of other plant organs. It was not until the start of fruit ripening that significant differences among treatments were observed in crown and root biomass, and starch content (Table 4). The soluble sugar content of specific plant organs (ranging from $50 \mathrm{mg}$ in roots to $1400 \mathrm{mg}$ in new leaves) was not significantly different among treatments at any harvest date in either year (data not presented; Bushway, 2000).

In both field experiments, first fruit ripened $\approx 4$ weeks after flowering in each particular treatment. Like flower development, fruit development in the elevated $\mathrm{CO}_{2}$ and rowcover treatments was 7 and $12 \mathrm{~d}$ ahead of the no cover and straw treatments, respectively (Fig. 3). Cumulative yield in 1998 (Expt. 4) was much lower in the straw treatment, while the difference among the other three treatments was only $\approx 7 \%$. In 1999 though (Expt. $5)$, cumulative yield was significantly different among these same three treatments $(P<0.001$, Fig. 3$)$. Yield per plant was $62 \%$ higher in the elevated $\mathrm{CO}_{2}$ and $48 \%$ higher in the rowcover treatment than without cover. Yield from the primary position, which produces the earliest and largest fruit, was essentially the same for all treatments (Fig. 4). Similarly, in both years, differences in the total number of fruit were greatest at the tertiary position (Fig. 5). There were no significant differences in size of fruit at each position.

\section{Discussion}

Early spring growth of new leaves in the perennial strawberry plant is associated with a rapid decline and near depletion of carbohydrate reserves that had accumulated in vegetative organs the previous fall (Long and Murneek, 1937; Nishizawa et al., 1998). In our study under traditional mulching practices, carbohydrate reserves declined significantly even before new leaf growth began (Table 1). Long and Murneek (1937) in Missouri also found comparable declines in these same plant characteristics in an Ozark adapted strawberry cultivar. Brierley and Landon (1944) reported that, toward the end of dormancy in late winter, strawberry plants showed a nearly 2 -fold increase in respiration even when the temperature remained constant. Together these findings suggest that increases in respiration at the end of dormancy may be largely responsible for declines in carbohydrate reserves during late winter. We observed no new leaf emergence before 17 Apr. even though there was a net loss in root, leaf, and crown biomass before then.

Reductions in carbohydrate pools early in the season could create a carbon-limited condition during flower and fruit development. This resource status could be a critical limitation to fruit production because several studies indicate that fruit dry matter accumulation depends on stored reserves in addition to current photosynthate (Darnell and Martin, 1988; Forney and Breen,

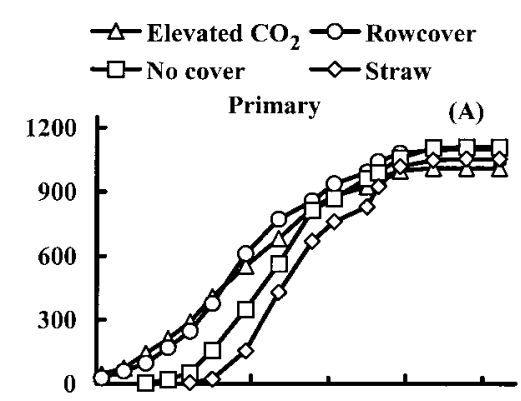
1985). Enhancing plant microclimate early in the season may promote an earlier functioning leaf surface and reduce depletion of carbohydrate pools early in the season.

Elevated $\mathrm{CO}_{2}$ in growth chambers significantly enhanced starch accumulation in strawberry crowns and leaves,

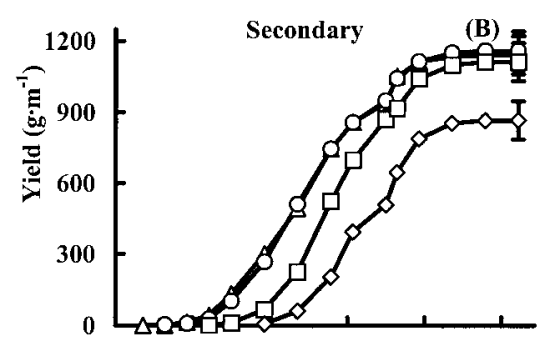
reduced the depletion of starch reserves in roots, and accelerated flower development. These findings are consistent with results from other experiments with strawberries using elevated $\mathrm{CO}_{2}$ (Chen et al., 1997b, 1997e; Chen and Lenz, 1997; Keutgen

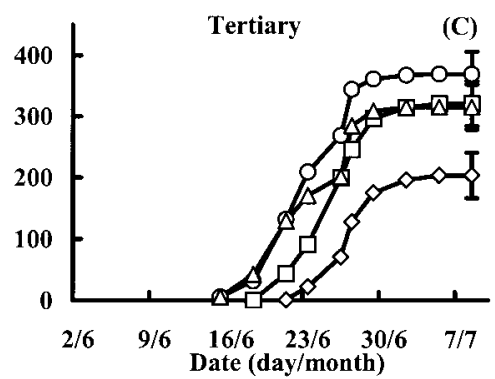
et al., 1997; Lieten, 1997). Though Campbell and Young (1986) note

Fig. 4. The effect of prebloom treatments on yield from $(\mathbf{A})$ primary, (B) secondary, and (C) tertiary fruit of 'Jewel' strawberry plants from June 1999 to July 1999 . Vertical bars = SE (n $=6$ ). 


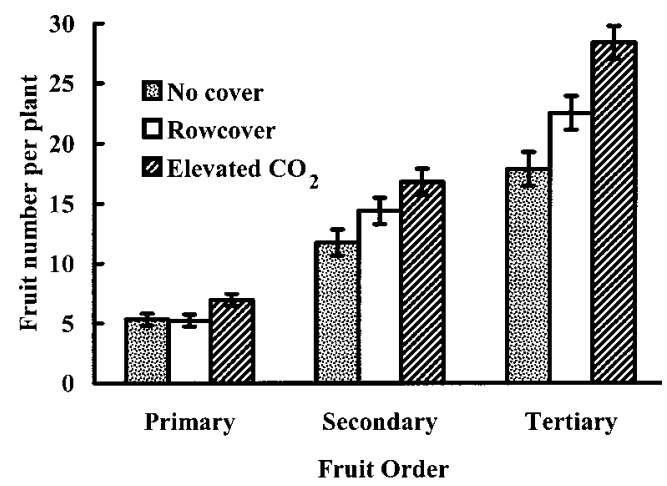

Fig. 5. Effect of prebloom treatments in the field on number of marketable primary, secondary, and tertiary fruit per plant of 'Jewel' strawberry in 1999. Vertical lines $=\mathrm{SE}$ $(n=6)$.

that elevated $\mathrm{CO}_{2}$ has been most beneficial to enhancement

of photosynthesis at warmer temperatures and at saturated light levels, in our growth chamber experiments, growth was enhanced at a relatively cool temperature $\left(15^{\circ} \mathrm{C}\right)$ and light levels $25 \%$ below previously reported saturation levels for strawberry leaves. Our findings, in combination with reports that older strawberry leaves can export $>50 \%$ of their current photoassimilates within a day of assimilation (Antosewski and Dzieciol, 1974; Nishizawa and Hori, 1986), suggest that overwintering leaves could play a key role early in the season. Enhancing their microclimate may promote carbon assimilation, accelerate new leaf development, and improve carbohydrate pools despite the lower temperature conditions of early spring.

In our field experiments, the translucent rowcover increased light availability compared to the opaque straw cover, and raised canopy and soil temperatures compared to no cover and straw mulch cover. Rowcover also made it possible to maintain elevated $\mathrm{CO}_{2}$ conditions around the strawberry plants in the early spring before bloom. As in the growth chamber, elevated $\mathrm{CO}_{2}$ conditions in the field increased photosynthetic rates of both overwintering and spring leaves. Enhanced carbon assimilation in a more favorable microclimate in early spring may have played a significant role in the observed improvements in plant development and plant carbohydrate resources. Exposure to increased light and warmer day temperatures by early removal of straw accelerated flower and fruit development in plants in the no cover treatment over plants in the straw treatment. The warmer temperatures under rowcover likely accelerated flower and fruit development, while elevated $\mathrm{CO}_{2}$ even further accelerated flower and fruit development. In other studies, when straw removal was delayed until late April, flower and fruit development were delayed (Boyce et al., 1988; Hertz and Struschonoff, 1982). When spring rowcover was used as an alternative to straw in the spring, flower and fruit development were accelerated (Dencker and Hansen, 1993: Gast and Pollard, 1991b; Gent, 1990).

Plants growing under rowcover before bloom had more root starch than plants with no cover. Exposure to elevated $\mathrm{CO}_{2}$ before bloom further enhanced root starch content. Gast and Pollard (1991a) also observed that plants under rowcover before bloom had a higher percentage of total nonstructural carbohydrates (TNSC) in their roots during fruit development than plants under straw until late April. Several other studies that examined the benefits of rowcover as an alternative to straw cover or no cover in the early spring reported enhancement of fruit production (Dencker and Hansen, 1993; Gast and Pollard 1991b; Gent, 1990; Pollard and Cundari, 1988; Pritts et al., 1989). Consistent with these studies, in our first field experiment, yields from plants left under straw until late April were $17 \%$ to $24 \%$ less than that of plants with spring rowcover or no spring cover. Further, in the second field experiment when a more uniform initial plant size was used, total fruit yield averaged $48 \%$ higher for plants under rowcover compared with those that had no cover. Early spring $\mathrm{CO}_{2}$ enrichment further enhanced fruit production by $9 \%$

Yield improvements under rowcover in the spring were attributed more to an increase in the number of marketable secondary and tertiary fruit rather than to an increase in fruit size. Other studies examining the benefits of rowcover in the early spring also found that improved yields were attributable to an increase in the number of subsidiary fruit (Dencker and Hansen, 1993; Gast and Pollard, 1991b; Gent, 1990; Pritts et al., 1989) due to increased development of already initiated inflorescenses. These outcomes are consistent with Hortynski et al. (1994) who stated that, within a cultivar, fruit size is less phenotypically plastic than fruit number, which is more influenced by environmental factors.

In conclusion, these studies demonstrate that enhancement of early spring microclimate can accelerate plant growth, enhance carbohydrate resources later in the season, and improve yields. Given the economic benefits that strawberry producers gain from earlier fruit production and enhanced yields, a cultural system that incorporates use of spring rowcover would be valuable to growers. If the rowcover is reused, yield increases as little as 10\%/ ha for 3 years in a field producing a typical $8,000 \mathrm{~kg} \cdot \mathrm{ha}^{-1}$ yield would make the economics of rowcover use favorable for growers.

Though it is clear that strawberry plants respond positively to elevated $\mathrm{CO}_{2}$ conditions, $\mathrm{CO}_{2}$ enrichment in early spring under rowcover was not economically viable. Greater success may be attained in a greenhouse because enrichment continues throughout flower and fruit development, while the enrichment period in the field is limited because the rowcover is removed at bloom to achieve adequate pollination. High tunnel systems might allow for successful introduction of insects and $\mathrm{CO}_{2}$ enrichment in the field. Further, though spunbonded rowcover is currently the most favorable rowcover material because it allows $80 \%$ to $85 \%$ light transmission but not excessive heat accumulation, $\mathrm{CO}_{2}$ gas readily dissipates through it. Consequently, a large quantity of $\mathrm{CO}_{2}$ gas is necessary to maintain elevated levels under this type of rowcover. Experimentation with other materials less permeable to $\mathrm{CO}_{2}$ would be valuable.

\section{Literature Cited}

Antoszewski, R. and U. Dzieciol. 1974. Translocation and accumulation of ${ }^{14} \mathrm{C}$-photosynthates in strawberry plant. Hort. Res. 13:75-81.

Boyce, B.R., A.W. Linde, and J. Aleong. 1988. Effect of delayed mulch removal on yield and harvest dates of 'Midway' strawberries. Adv. Strawberry Prod. 7:29-31.

Boyce, B.R. and R.A. Reed. 1983. Effect of bed height and mulch on strawberry crown temperatures and winter injury. Adv. Strawberry Prod. 2:12-14.

Brierley, W.G. and R.H. Landon. 1944. Winter behavior of strawberry plants. Minn. Agr. Expt. Sta. Bul. 375:6-24.

Bushway, L.J. 2000. Early spring microclimate affects carbon resources and productivity in June-bearing strawberry. MS thesis, Cornell Univ., Ithaca, N.Y.

Cairns, A.J. 1987. Colormetric microtiter plate assay of glucose and fructose by enzyme-linked formazan production: Applicability to the measure of fructosyl transferase activity in higher plants. Anal. Biochem. 167:270-278.

Campbell, D.E. and R. Young. 1986. Short-term carbon dioxide exchange response to temperature, irradiance and carbon dioxide concentration in strawberry. Photosyn. Res. 8:31-40.

Chen, K., G. Hu, N. Keutgen, and F. Lenz. 1997a. Effects of CO concentration on strawberry. I. Plant growth analysis. J. Appl. Bot. 71:168-172. 
Chen, K., G. Hu, N. Keutgen, and F. Lenz. 1997b. Effects of $\mathrm{CO}_{2}$ concentration on strawberry. II. Leaf photosynthetic function. J. Appl. Bot. 71:173-178.

Chen, K., G. Hu, N. Keutgen, and F. Lenz. 1997c. Effects of $\mathrm{CO}_{2}$ concentration on strawberry. III. Dry matter production and water consumption. J. Appl. Bot. 71:179-182.

Chen, K., G. Hu, and F. Lenz. 1997d. Effects of $\mathrm{CO}_{2}$ concentration on strawberry. III. Carbohydrate production and accumulation. J. Appl. Bot. 71:183-188.

Chen, K., G. Hu, and F. Lenz. 1997e. Effects of $\mathrm{CO}_{2}$ concentration on strawberry. VI. Fruit yield and quality. J. Appl. Bot. 71:195-200.

Chen, K. and F. Lenz. 1997. Responses of strawberry to doubled $\mathrm{CO}_{2}$ concentration and phosphorus deficiency. I. Distribution of dry matter, macronutrients and carbohydrates. Gartenbauwissenschaft 62:30-37.

Collins, W.B. 1966. Effects of winter mulches on strawberry yield. J. Amer. Soc. Hort. Sci. 89:331-335.

Darnell, R.L. and G.C. Martin. 1988. Role of assimilates translocation and carbohydrate accumulation in fruit set of strawberry. J. Amer. Soc. Hort. Sci. 113:114-118.

Dencker, V. and P. Hansen. 1993. Effects of winter cover on yield components of 'Elsanta' strawberries. Acta Agr. Scandinavica 43:168171.

Deng, X. and F.I. Woodward. 1998. The growth and yield response of Fragaria xananassa to elevated $\mathrm{CO}_{2}$ and $\mathrm{N}$ supply. Ann. Bot. 81:67-71.

Ferree, D.C. and E.J. Stang. 1988. Seasonal plant shading, growth, and fruiting in 'Earligrow' strawberry. J. Amer. Soc. Hort. Sci. 113:322327.

Forney, C.F. and P.J. Breen. 1985. Dry matter partitioning and assimilation in fruiting and deblossomed strawberry. J. Amer. Soc. Hort. Sci. 110:181-185.

Gast, K.L.B. and J.E. Pollard. 1989. Seasonal differences in soluble and insoluble nonstructural carbohydrates in rowcovered and nonrowcovered strawberry. Acta Hort. 265:369-376.

Gast, K. L. B. and J.E. Pollard. 1991a. Rowcover and mulch alter seasonal strawberry carbon metabolism. HortScience 26:421.

Gast, K.L.B. and J.E. Pollard. 1991b. Rowcover enhance reproductive and vegetative yield components in strawberries. HortScience 26:14671469.

Gent, M.P.N. 1990. Ripening and fruit weight of eight strawberry cultivars respond to row cover removal date. J. Amer. Soc. Hort. Sci. 115:202-207.

Hamamota, H. 1996. Effect of non-woven rowcover on plant environment and growth. Jpn. Agr. Res. Quarterly 30:49-53.

Hartz, T.K., A. Baameur, and D.B. Holt. 1991. Carbon dioxide enrich- ment of high-value crops under tunnel culture. J. Amer. Soc. Hort. Sci. 116:970-973.

Hertz, L.B. and C. Struschonoff. 1982. The effect of sudangrass straw and poly-foam mulches when used as winter protectants on the growth and yield of 'Redcoat' strawberries. Fruit Var. J. 4:57-59

Hortynski, J.A., K. Liniewicz, and T. Hulewicz. 1994. Influence of some atmospheric factors affecting yield and single fruit weight in strawberry. J. Hort. Sci. 69:89-95.

Kerkhoff, K.L., J.M. Williams, and J.A. Barden. 1988. Net photosynthesis rates and growth of strawberries after partial defoliation. HortScience 23:1086

Keutgen, N., K. Chen, and F. Lenz. 1997. Responses of strawberry leaf photosynthesis, chlorophyll fluorescence and macronutrients contents to elevated $\mathrm{CO}_{2}$. J. Plant Physiol. 150:395-400.

Lieten, F. 1997. Effect of $\mathrm{CO}_{2}$ enrichment on greenhouse grown strawberry. Acta Hort. 439:583-587.

Long, J.H. and A.E. Murneek. 1937. Nitrogen and carbohydrate content of the strawberry plant: Seasonal changes and the effect of fertilizers. Univ. Mo. Agr. Expt. Sta. Res. Bul. 252.

Loy, J.B. and O.S. Wells. 1982. A comparison of slitted polyethylene and spun-bonded polyester for plant row covers. HortScience 17:405-407.

May, G.M., M.P. Pritts, and M.J. Kelly. 1994. Seasonal patterns of growth and tissue nutrient content in strawberries. J. Plant Nutr. 17:149-1162.

Nishizawa, T. and Y. Hori. 1986. Translocation of ${ }^{14} \mathrm{C}$-assimilates from leaves of strawberry plants in vegetative stage as affected by leaf age and position. J. Jpn. Hort. Sci. 54:467-476.

Nishizawa, T., Y. Shishido, and H. Kumakura. 1998. Mobilization of ${ }^{14} \mathrm{C}$-carbohydrate reserves in relation to vegetative growth and inflorescence development in June bearing strawberry plants. J. Hort. Sci. Biotechnol. 73:499-505.

Pollard, J.E. and C.M. Cundari. 1988. Overwintering strawberries under rowcover increases fruit production. HortScience 23:32-33.

Pritts, M.P. and D.T. Handley. 1998. Strawberry production guide. Natural Resources, Agr. Eng. Serv., Ithaca, N.Y.

Pritts, M.P., K.A. Worden, and M. Eames-Sheavly. 1989. Rowcover material and time of application and removal affect ripening and yield of strawberries. J. Amer. Soc. Hort. Sci. 114:531-536.

Shoemaker, J.S. 1975. Small fruit culture. 4th ed. AVI Publishing, Westport, Conn.

Setter, T.L. 1996. Glucose, fructose, sucrose and starch assay: A laboratory protocol. Dept. Crop Soil Sci., Cornell Univ., Ithaca, N.Y.

Sung, F.J.M and J.J. Chen. 1991. Gas exchange rate and yield response of strawberry to carbon dioxide enrichment. Scientia Hort. 48:241-252. 